\title{
Benedetta Ubertazzi: Exclusive Jurisdiction in Intellectual Property, Max-Planck-Institut für Ausländisches und Internationales Privatrecht, Studien zum Ausländischen und Internationalen Privatrecht, Vol. 273. Tübingen, Mohr Siebeck 2012. pp. XVIII, 341. ISBN: 978-3-16-151954-3. $€ 69.00$
}

\author{
Paul L. C. Torremans \\ Published online: 8 January 2013 \\ (C) Max Planck Institute for Intellectual Property and Competition Law, Munich 2012
}

Exclusive jurisdiction in intellectual property cases is a divisive topic, to say the very least. It is also almost an emotive topic. Without necessarily thinking of boundaries or potential justifications, intellectual property or private international law experts either feel that it should obviously have a place or that it is a mere gremlin one needs to get rid of as soon as possible. In short, this is a minefield! Bizarre as it may sound though, Benedetta Ubertazzi seems to feel very much at home in this minefield. She is not merely writing another emotive pamphlet against or in favour of exclusive jurisdiction in intellectual property; instead she is carefully demining the field.

Dr. Ubertazzi is indeed well placed to conduct such a difficult exercise. She has been involved with intellectual property and with private international law issues surrounding them for a number of years, as well as with the various international attempts to come up with a coherent set of rules on all aspects of the relationship between intellectual property and private international law. She therefore possesses in-depth knowledge of the issue at hand. But one should not forget that above all she is a scholar in public international law, and the most often mentioned justifications to keep the exclusive jurisdiction exception in the area of intellectual property have their roots in public international law. She therefore brings together the three areas that are indispensible for bringing a project such as this one to a coherent and comprehensive conclusion, i.e. intellectual property law, private international law and public international law.

In a first stage, the project is explained in some detail. What emerges here as a key point is the importance of fully understanding the (limited) scope of the exclusive jurisdiction exception in intellectual property. Private international law is

P. L. C. Torremans $(\bowtie)$

Dr., Professor of Intellectual Property Law, University of Nottingham

School of Law, University of Nottingham, Law and Social Sciences Building,

University Park, Nottingham NG7 2RD, UK

e-mail: paul.torremans@nottingham.ac.uk 
no longer based on a concept of exclusive jurisdiction, and any use of it is therefore limited in scope. But it is vital to understand that the various instruments available in the not very harmonised world of private international law do not even impose the exceptional exclusive jurisdiction rule to intellectual property as a whole. Cases dealing with the infringement of intellectual property are (in general) not at all touched by the rule on exclusive jurisdiction. Exclusive jurisdiction rules are overall carefully limited to issues of validity. And even then, only the validity of registered rights is covered, copyright therefore being exempt, and there is increasing evidence that most rules on exclusive jurisdiction in intellectual property do not cover the situation where validity is raised merely incidentally. In other words, what is offered to the reader is a very carefully balanced and detailed definition of the topic of the book. What exactly do we mean by exclusive jurisdiction in intellectual property? Where does it start? And how far does it go? This is a vital first step in the light of what is to follow.

Vital as it may be, it is only a prelude. The essence of the book is a careful analysis of the (primarily) public international law principles that are used to justify the carefully circumscribed exclusive jurisdiction exception.

The involvement of state agencies in the granting of registered intellectual property rights seems to have been the main trigger for certain recent decisions on exclusive jurisdiction in intellectual property to make reference to, or rather to rely very strongly on, the act of state doctrine and the comity doctrine. Both doctrines have an impressive pedigree in public international law, and one does not do them any form of justice by reducing them to the consequence that judges are inclined or even obliged to stay out of the affairs of the other country involved. But that is in essence what certain intellectual property judges have concluded. The grant of a registered intellectual property right amounts to an act of state by the foreign state. As an examination of its validity could potentially undo such a grant, this is an area where one should abstain - and an exclusive jurisdiction rule allows you to do just that. Or if one wishes to put it in comity terms, the respect for the other state and its sovereign decisions obliges you not to interfere with the grant of the intellectual property right. Chapter III offers a strong rebuttal of this approach. The relevant doctrines are examined carefully and in detail, and the conclusion is reached that the act of state doctrine and comity do not mandate exclusive jurisdiction rules-and neither do they justify their use.

Chapter IV then shifts the focus to that other grand theory that keeps resurfacing in the area of intellectual property and in public international law: the territoriality principle. The territoriality principle essentially means that a state's competences are limited to its own borders. It is indeed easy to see how one could derive from this principle a rule of exclusive jurisdiction limiting the jurisdiction of the courts of a state to the cases relating to intellectual property rights granted by that state and registered in that state. Once again, the fallacy of the argument is exposed, and it is overwhelmingly proven that the territoriality principle does not mandate exclusive jurisdiction rules.

There is, in other words, no international law obligation to have exclusive jurisdiction rules, and international law does not offer a justification for a decision to nevertheless have them. But the book does not end here. Chapter VI does indeed 
offer an insight into the consequences of the operation of exclusive jurisdiction rules in intellectual property. The picture that emerges is alarming. There is evidence that in quite a number of situations, exclusive jurisdiction rules (as they are often coupled with a rule on the non-recognition of foreign judgments in this area) lead to a denial of justice. In those cases, the rightholder will not be able to bring his case in an effective way in any jurisdiction, and the right will become de facto unenforceable. That involves a clear violation of the fundamental human right of access to courts.

The analysis therefore leads Dr. Ubertazzi to a very clear conclusion. Exclusive jurisdiction in intellectual property cannot be justified any longer and should therefore be abandoned. But one should not merely read this book for its conclusion. Its careful analysis that leaves no stone unturned is inspiring and a goldmine for any researcher in this area. This book clearly deserves a place in any legal library that covers intellectual property, public and private international law. It makes an essential contribution to the advancement of legal science in this area. 